\title{
Inflammation-mediated fetal injury by maternal granulocyte-colony stimulating factor and high-dose intra- amniotic endotoxin in the caprine model
}

\section{Maternal granülosit koloni stimülan faktör ve yüksek doz intra-amniyotik endotoksin ile enflamasyon aracil fetal beyin hasarı keçi modeli}

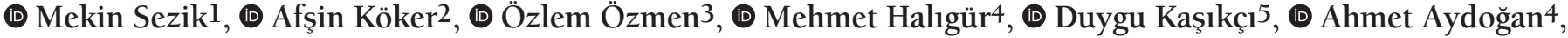 (1) Orhan Özatik6}

1Süleyman Demirel University Faculty of Medicine, Department of Obstetrics and Gynecology, Isparta, Turkey

2 Mehmet Akif Ersoy University Faculty of Veterinary Medicine, Department of Obstetrics and Gynecology, Burdur, Turkey

${ }^{3}$ Mehmet Akif Ersoy University Faculty of Veterinary Medicine, Department of Pathology, Burdur, Turkey

${ }^{4}$ Çukurova University Faculty of Ceyhan Veterinary Medicine, Department of Pathology, Adana, Turkey

5Isparta University of Applied Sciences Faculty of Agricultural Sciences and Technologies, Department of Animal Science, Isparta, Turkey

${ }^{6}$ Kütahya Health Sciences University Faculty of Medicine, Department of Histology and Embryology, Kütahya, Turkey

\begin{abstract}
Objective: To define a novel experimental model with maternal intravenous (i.v.) granulocyte-colony stimulating factor (G-CSF) followed by a single- and high-dose of $20 \mathrm{mg}$ intra-amniotic (IA) endotoxin to induce fetal brain injury in the preterm fetal goat.

Materials and Methods: Pregnant goats $(n=4)$ were given 50 microg/day G-CSF into the maternal jugular vein through gestational days $110-115$ (term, 150 days). At gestational day 115, $20 \mathrm{mg}$ of IA endotoxin was administered. Following preterm delivery at day 120 by cesarean section umbilical cord, fetal lung and brain tissues were harvested for histopathology, immunohistochemistry, and electron microscopy. Inflammatory markers were evaluated in the amniotic fluid and fetal plasma.

Results: Necrotizing funisitis with abundant leukocyte infiltration and fetal brain injury was induced in all the fetuses in the experimental group. Conclusion: Maternal i.v. G-CSF for 5 days followed by $20 \mathrm{mg}$ of IA endotoxin is a feasible caprine model to exacerbate intrauterine inflammation. Keywords: Animal model, endotoxins, cerebral palsy, chorioamnionitis, inflammation

$\ddot{\mathrm{O} z}$

Amaç: Preterm gebe keçide fetal beyin hasarı oluşturmak için maternal intravenöz (i.v.) granülosit koloni stimulan faktör (G-CSF) sonrasında amniyon içine tek ve yüksek-doz 20 mg endotoksin verilmesini içeren yeni deneysel modelin tanımlanmasıdır.

Gereç ve Yöntemler: Gebeliğin 110-115. günlerinde (term: 150 gün) keçilere (n=4) jugular ven yoluyla 50 mikrog/gün G-CSF verildi. Gebeliğin 115. gününde, $20 \mathrm{mg} I A$ endotoksin uyguland. Gebeliğin 120. gününde sezaryen ile preterm doğumu takiben umblikal kord, fetal akciğer ve beyin örnekleri histopatoloji, immünhistokimya ve elektron mikroskobu incelemeleri için elde edildi. Amniyon sıvısı ve fetal plazmada enflamatuvar belirteçler değerlendirildi.

Bulgular: Deney grubundaki fetüslerin tümünde, belirgin lökosit infiltrasyonu ile şekillenen nekrotizan funisit ve fetal beyin hasarının geliştiği saptandı. Sonuç: Şiddetli intrauterin enflamasyon oluşturmak için 5 gün maternal i.v. G-CSF ve takiben 20 mg IA endotoksin uygulamalarını içeren keçi modelinin uygulanabilir olduğu sonucuna varıldı.

Anahtar Kelimeler: Hayvan modeli, endotoksinler, serebral palsi, koryoamniyonit, enflamasyon
\end{abstract}

PRECIS: Using low-dose maternal G-CSF and high-dose IA endotoxin, we have defined a feasible animal model of inflammationmediated fetal injury in the preterm goat.

Address for Correspondence/Yazışma Adresi: Mekin Sezik, MD,

Süleyman Demirel University Faculty of Medicine, Department of Obstetrics and Gynecology, Isparta, Turkey

Phone: +90 5414337157 E-mail: msezik@yahoo.com ORCID ID: orcid.org/0000-0002-6989-081X

Received/Gelis Tarihi: 25.11.2018 Accepted/Kabul Tarihi: 20.01.2019

Data was partially presented as an abstract at the 24th World Congress on Ultrasound in Obstetrics Gynecology, 14-17 September 2014, Barcelona, Spain.

${ }^{\oplus}$ Copyright 2019 by Turkish Society of Obstetrics and Gynecology

Turkish Journal of Obstetrics and Gynecology published by Galenos Publishing House 


\section{Introduction}

Fetoplacental inflammation secondary to intra-amniotic (IA) microbial colonization and subclinical chorioamnionitis provide a basis for the development of preterm birth and cerebral palsy (CP) by preferentially affecting the fetal brain tissue. Increased number of experimental and clinical work previously focused on fetoplacental inflammation and fetal brain injury. Therefore, animal models to aggravate intrauterine inflammation were often required and used ${ }^{(1)}$. Within this context, the preterm small ruminant (such as sheep and goat) models that exclusively used IA endotoxin were accepted as relatively suitable designs to induce fetal lung and brain injury ${ }^{(2,3)}$.

Granulocyte-colony stimulating factor (G-CSF) is a hemopoietic growth factor involved in the control of neutrophil numbers. G-CSF expression is increased in response to infection or injury. Therefore, a proinflammatory role of G-CSF has been suggested, secondary to increased neutrophil production and migration to the inflamed site $e^{(4)}$. Here, we aim to define our experience with intravenous (i.v.) recombinant (G-CSF) administrations for 5 days followed by a single-dose of $20 \mathrm{mg}$ of IA endotoxin to induce IA inflammation, necrotizing funisitis, and fetal brain/lung injury in the preterm goat model. Previous small ruminant models for this purpose have not previously used combined IA highdose endotoxin and systemic G-CSF administrations ${ }^{(1-3)}$. Moreover, maternal i.v. bolus injections of G-CSF have not been utilized before. Hence, we hypothesized that our novel and relatively simple experimental model that does not require chronic maternal or fetal instrumentation would be able to produce exacerbated inflammation in utero, at least to an extent of that observed in previous experiments ${ }^{(1-3,5-7)}$.

\section{Materials and Methods}

The current study includes data on preliminary experimental groups (model and controls) formed prior to the main intervention study testing the effects of pentoxifylline on fetal brain injury ${ }^{(8)}$. The study protocol was subject to animal ethics committee approval by Süleyman Demirel University Animal Experimentation Local Ethics Committee (approval date and no, 23.08.2011/03). Principles of laboratory animal care (NIH publication No. 86-23, revised 1985) were followed, as well as specific national laws where applicable. Eight date-mated singleton pregnant hair goats (Capra hircus) at age of 4-5 years and prepregnancy body weight of $40 \pm 5 \mathrm{~kg}$ were included. Term pregnancy in hair goats is around 150 days. A singleton structurally normal ongoing pregnancy and accurate fetal biometry was confirmed by ultrasonography (BCF Easi Scan, Dundalk, Ireland) at days 28, 43, 58, 73, and 88 of pregnancy. The does were sheltered in a semi-open pen and reared on pasture and/or standard food. Water and mineral salts were provided ad libitum.
At day 110 of gestation, animals were transported to the animal clinics at the Faculty of Veterinary Medicine, Mehmet Akif Ersoy University. Randomization into 2 groups was carried out: Control (group 1, n=4) and the experimental model (group 2, n=4) groups. At gestational days 110 through 115, animals in the model group were given 50 microg/ day i.v. bolus injections of G-CSF (Neupogen Roche, F. Hoffmann-La Roche Ltd, Basel, Switzerland) solubilized in 2 $\mathrm{ml}$ of normal saline for 5 days, whereas the controls received $2 \mathrm{ml}$ of i.v. normal saline only. Jugular vein was used for all i.v. administrations.

At day 115, amniocentesis was performed as defined previously ${ }^{(9)}$. Following sterilization of the abdomen with povidine-iodine, a 20-gauge amniocentesis needle was inserted into the amniotic cavity under ultrasound guidance, and $10 \mathrm{ml}$ of amniotic fluid was sampled. Erroneous access into the allantois was excluded by the color and viscosity of the sample ${ }^{(10)}$. Following sampling in the model group, $20 \mathrm{mg}$ of endotoxin solution (Lipopolysaccharides from Escherichia coli 055:B5, L 2880, Sigma-Aldrich, Missouri, USA) was administered intra-amniotically, using the same needle under strict ultrasound guidance. The controls received identical amount of normal saline into the amniotic cavity.

Cesarean sections were performed with minor modifications to our previously reported technique ${ }^{(11,12)}$. Approximately 120 $\mathrm{h}$ after the amniocentesis procedures (day 120) corresponding to 0.80 of gestation, preterm birth was induced by cesarean section. The does were sedated with $0.25 \mathrm{mg} / \mathrm{kg}$ xylazine (Rompun, Bayer, Germany) and given epidural anesthesia with $25 \mathrm{mg}$ lidocaine and $0.016 \mathrm{mg}$ epinephrine (Jetokain, Adeka, Samsun, Turkey) into the sacrococcygeal space. Local infiltrative anesthesia with $25 \mathrm{mg}$ lidocaine into the presumed incision line was also used. Following a 10-cm paralumbar skin incision, uterus was opened from its dorsal curvature. Prior to amniotomy, $10 \mathrm{~mL}$ of amniotic fluid was aspirated with a sterile injector, followed by delivery of the neonate. Tissue samples from fetal membranes, umbilical cord, and placenta were also harvested appropriately. Postoperatively, the does received i.m. antibiotics (200 $\mathrm{mg}$ procain penicillin plus $250 \mathrm{mg}$ dihydrostreptomycin sulfate; Diperinisol, Bayer, İstanbul, Turkey) and analgesia with i.m. metamizole sodium (Novalgin ampoule, PharmaVision, Istanbul, Turkey).

Following drying and weighing, the kids were given 50 $\mathrm{mg} / \mathrm{kg}$ intraperitoneal sodium thiopental (Pental Sodyum, IE Ulugay, Istanbul, Turkey) for euthanasia ${ }^{(9,11)}$. Then, intracardiac blood was sampled via the transthoracic route and chest opened followed by en bloc dissection of the lungs and brain ${ }^{(11)}$. Pulmonary parenchyma and cerebral white matter were sampled.

For routine histopathology and immunohistochemistry (IHC), tissue samples were fixed in $10 \%$ buffered formaldehyde and embedded into paraffin with routine processing for further histopathological and immunohistochemical staining. For 
transmission electron microscopy (TEM), tissue samples were carefully sliced into approximately $1-\mathrm{mm}^{3}$ pieces on a petri dish that contained buffered glutaraldehyde $(2.5 \%, \mathrm{pH}$, $7.2)$ as a fixative. Sliced tissues were transferred into fixativecontaining dark-colored bottles, kept at $4{ }^{\circ} \mathrm{C}$ for $24 \mathrm{~h}$ and transported to the TEM laboratory.

For IHC evaluations fetal lung samples were stained with surfactant proteins A, B, C, and D (Santa Cruz Biotechnology Inc, USA), prosurfactant protein B (Abcam, UK), interleukin-1, interleukin-4, interleukin-6, interleukin-10, tumor necrosis factor (TNF)-alpha, caspase 3, caspase 5, caspase 7, COX-1, COX-2, interferon-alpha, and interferon-beta (Abcam, UK).

Fetal brain samples were immunostained with interleukin-1, interleukin-4, interleukin-6, interleukin-10, TNF- alpha, caspase 3 , caspase 5 , caspase $7, \mathrm{COX}-1, \mathrm{COX}-2$, interferonalpha and interferon-beta, neuron specific enolase (NSE), glial fibrillary acidic protein (GFAP) (Abcam, UK), apoptosis protease activating factor (Biosensis, Australia), vimentin (Abcam, UK), anti-neurofilament protein (NFP) (Abcam, UK), and anti-myelin basic protein (MBP) (Abcam, UK).

Placentae and fetal membranes were stained for interleukin-1, interleukin-4, interleukin-6, interleukin-10, TNF-alpha, caspase 3, caspase 5, caspase 7, COX-1, COX-2, interferonalpha, and interferon-beta. Commercial kits were used for IHC examinations, using a routine streptavidine-biotin peroxidase technique.

To evaluate the severity of the IHC reactions semiquantitative analyses were performed, using an arbitrary visual scale with a grading score ranging from 0 to 3 as follows: $(0)=$ negative, $(1)=$ weak staining, $(2)=$ moderate staining, and (3) = diffuse staining. Olympus CX41 light microscope and the Database Manual Cell Sens Life Science Imaging Software System (Olympus Corporation, Tokyo, Japan) were used for examinations. The pathologists were blinded to the experimental groups.

Samples were bleached in propylene oxide and placed into 1/1 propylene-oxidized araldehyde for $2 \mathrm{~h}$ and soaked in pure araldehyde overnight. Afterwards, the specimens were embedded in araldehyde and polymerized at $60{ }^{\circ} \mathrm{C}$ for 48 h. The $700 \mathrm{~nm}$ sections were cut at ultra-microtome (Leica Ultracut R, Leica Microsystem, Austria), and stained with toluidine blue and examined by light microscope (Olympus BX50, Olympus, Tokyo, Japan). Selected areas were trimmed and 60-nm thin sections were stained with uranyl acetate and lead citrate, and examined by JEOL JEM1220 Transmission Electron Microscope (Nippon Denshi Co, Tokyo, Japan).

On lung sections, ultra-structural changes such as increase in goblet cells, secretory components of goblet cells, endoplasmic reticulum in goblet cells, protein synthesis, cilial degenerations, neutrophil, lymphocyte and plasma cells infiltrations, increase in intracellular ribosomes, and thickness of noncellular basal membranes were examined. In brain tissues, increase in polymorphonuclear leukocyte in perivascular areas and demyelination were evaluated.
Interleukin and TNF-alpha levels in plasma and amniotic fluid samples were evaluated by the double antibody sandwich enzyme-linked immunosorbent assay (ELISA) method. Commercial kits for goat serum provided from Eastbiopharm (Hangzhou, China) were used for TNF-alpha, interleukin-1, interleukin-4, interleukin-6, and interleukin-10. Results were evaluated at $450 \mathrm{~nm}$, and optic density (OD) values were calculated and standardized accordingly.

\section{Statistical Analysis}

Variables were expressed as median and interquartile ranges given within brackets. Mann-Whitney U test was used for comparisons across the two groups. Wilcoxon signed-rank test was used to compare amniotic fluid measurements (at day 115 and 120) within the groups A two-sided $p<0.05$ was considered as significant for all analyses.

\section{Results}

Macroscopically, the umbilical cords from group 1 (controls) were normal, whereas hemorrhage and edema were evident in the model group. Microscopically, funisitis and vasculitis characterized by extensive inflammatory reaction including the Wharton jelly were present in endotoxin-exposed animals. This was characterized by necrotic arcs of inflammatory debris around all vessels made up of degenerated neutrophils in the Wharton's jelly, showing areas of inflammatory debris and neovascularization. Most of the infiltrating cells were neutrophils, while lymphocytes and plasma cells were also observed. Thrombi were observed in some of the umbilical vessel sections. Fetal membranes from group 1 were normal, whereas extensive inflammatory reaction and desquamation at the epithelial cells with areas of hemorrhage were present in membranes from the model animals. In some specimens, aggregates of bacteria presumably due to cervical dilatation secondary to inflammation in fetal membranes specific to goats or contamination were also evident (Figure 1, Figure 2).

Pulmonary sections from group 1 revealed thin septal walls, concordant with normal preterm lungs. G-CSF plus endotoxin-exposed kids had thickened and edematous septal walls accompanied by increased alveolar macrophages and neutrophilic infiltrations. Routine histopathology did not reveal any distinctive findings in the brain tissues except hyperemia and mild gliosis in a kid from group 2.

IHC results were in parallel with histopathology. Comparisons of the staining intensities across the groups are given in Table 1, revealing significant differences for all the studied parameters. Inflammatory markers including various interleukins were increased in all tissues. Moreover, specimens from the model group generally stained heavily for the apoptosis markers. Fetal brain injury was apparent in the model animals, shown by decreased NSE, NFP, GFP, and MBP staining compared to controls (Table 1). 


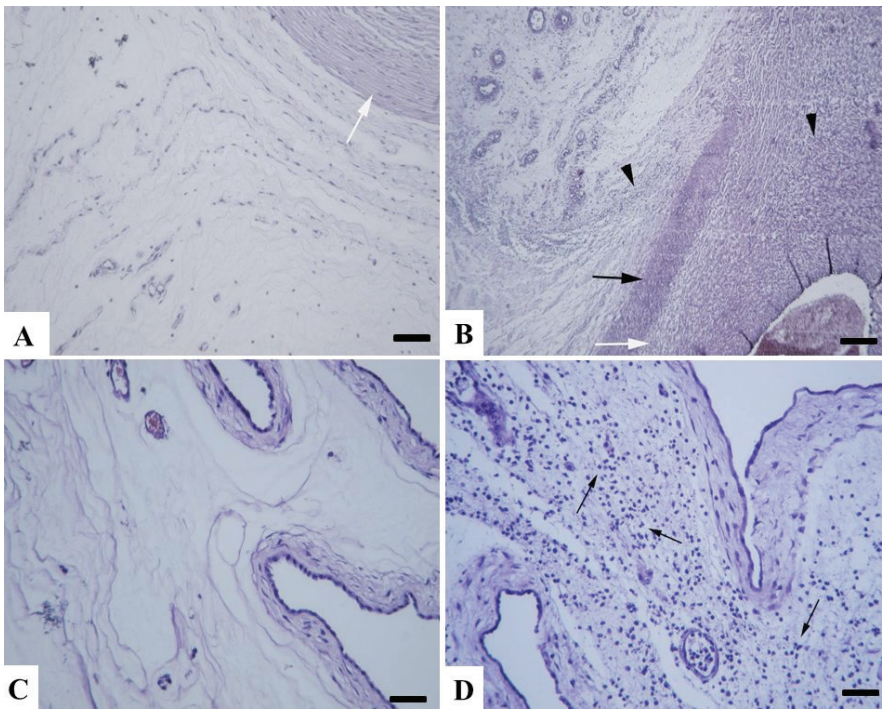

Figure 1. Umbilical cord and fetal membrane histopathology. (A) Normal appearance of umbilical cord from a kid in the control group, umbilical vessel (white arrow) (B) Severe funisitis characterized by inflammatory cell infiltrations (arrow heads) and necrotic arcs (black arrow) of inflammatory debris around the umbilical vessel (white arrow) and neovascularization (upper left side of the picture) from the model group. (C) Histology of normal fetal membranes from the control group. (D) Inflammation of fetal membranes showing numerous inflammatory cells (arrows) from model group, HE, Bar $=100 \mu \mathrm{m}$

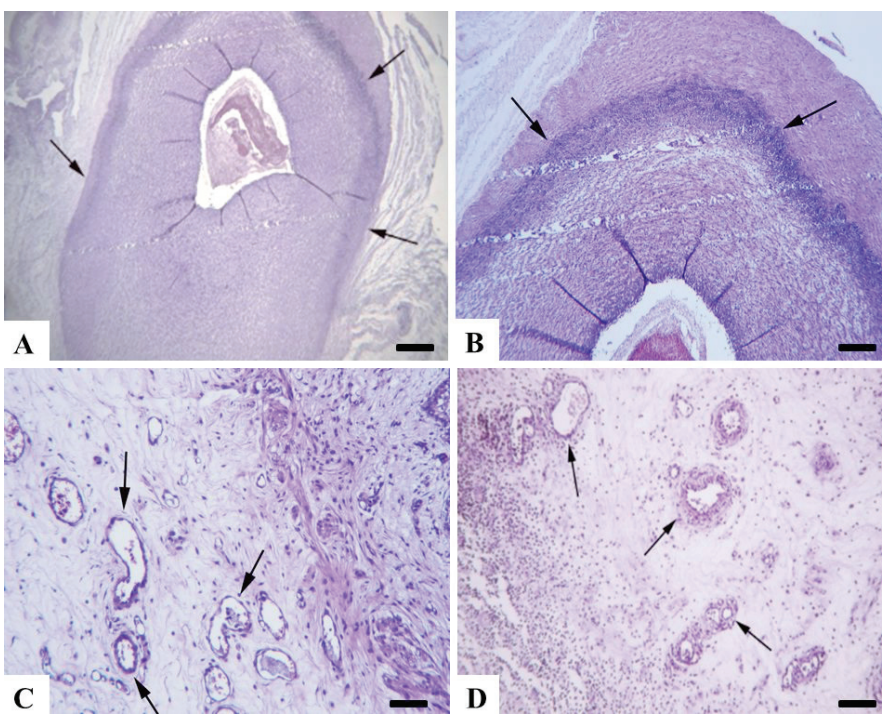

Figure 2. Umbilical vessel histopathology. (A) Marked necrotic arc (arrows) in vascular wall of the umbilical vessel, Bar $=200$ $\mu \mathrm{m}$. (B) Higher magnification of the necrotic arc, Bar $=100 \mu \mathrm{m}$. (C and D) Neovascularization (arrows) in umbilical cord, HE, Bars $=100 \mu \mathrm{m}$

Selected IHC sections showing staining properties are shown in Figure 3 and Figure 4. Brain IHC revealed decreased immunoreaction in brain markers in the model group. While surfactant protein expirations were decreased, apoptotic
Table 1. Comparisons of immunohistochemical staining intensities across the groups

\begin{tabular}{l|l|l|l} 
Marker & $\begin{array}{l}\text { Group 1 } \\
\text { controls } \\
(n=4)\end{array}$ & $\begin{array}{l}\text { Group 2 } \\
\text { model } \\
(n=4)\end{array}$ & p-value
\end{tabular}

Fetal brain

\begin{tabular}{llll} 
Interleukin-1 & $0(0-0.75)$ & $3(3-3)$ & 0.011 \\
\hline Interleukin-4 & $0(0-0.75)$ & $2(2-2.75)$ & 0.015 \\
\hline Interleukin-6 & $0(0-0.75)$ & $3(1.5-3)$ & 0.022 \\
\hline Interleukin-10 & $0(0-0.75)$ & $3(2.25-3)$ & 0.015 \\
\hline Interferon-alpha & $0(0-0.75)$ & $3(2.25-3)$ & 0.015 \\
\hline Interferon-beta & $0(0-0.75)$ & $3(2.25-3)$ & 0.015 \\
\hline $\begin{array}{l}\text { Tumor necrosis factor- } \\
\text { alpha }\end{array}$ & $0(0-0.75)$ & $3(3-3)$ & 0.011 \\
\hline Caspase 3 & $0(0-0.75)$ & $3(2.25-3)$ & 0.015 \\
\hline Caspase 5 & $0(0-0.75)$ & $2(2-2.75)$ & 0.015 \\
\hline Caspase 7 & $0(0-0.75)$ & $2(2-2.75)$ & 0.015 \\
\hline Cyclooxygenase-1 & $0.5(0-1)$ & $2.5(2-3)$ & 0.018 \\
\hline Cyclooxygenase-2 & $0(0-0.75)$ & $2.5(1.25-3)$ & 0.025 \\
\hline Vimentin & $3(3-3)$ & $1.5(1-2)$ & 0.013 \\
\hline Neuron specific enolase & $3(3-3)$ & $0.5(0-1)$ & 0.013 \\
\hline Neurofilament protein & $3(3-3)$ & $1(0.25-1.75)$ & 0.013 \\
\hline $\begin{array}{l}\text { Glial fibrillary acidic } \\
\text { protein }\end{array}$ & $3(3-3)$ & $1(1-2.5)$ & 0.04 \\
\hline Myelin basic protein & $3(3-3)$ & $1(1-2.5)$ & 0.04 \\
\hline $\begin{array}{l}\text { Apoptotic protease } \\
\text { activating factor 1 }\end{array}$ & $2.5(2-3)$ & $0(0-0.75)$ & 0.017 \\
\hline
\end{tabular}

Fetal lung

\begin{tabular}{llll} 
Interleukin-1 & $0(0-0.75)$ & $3(3-3)$ & 0.011 \\
Interleukin-4 & $0(0-0.75)$ & $3(2.25-3)$ & 0.015 \\
Interleukin-6 & $0.5(0-1)$ & $2.5(2-3)$ & 0.018 \\
Interleukin-10 & $0(0-0.75)$ & $2.5(2-3)$ & 0.017 \\
\hline Interferon-alpha & $0(0-0.75)$ & $3(3-3)$ & 0.011 \\
\hline Interferon-beta & $0(0-0.75)$ & $3(2.25-3)$ & 0.015 \\
Tumor necrosis factor- & $0(0-0.75)$ & $3(2.25-3)$ & 0.015 \\
alpha & & & \\
Caspase 3 & $0(0-0.75)$ & $2.5(2-3)$ & 0.017 \\
Caspase 5 & $0(0-0.75)$ & $2(2-2.75)$ & 0.015 \\
Caspase 7 & $1(0.25-1)$ & $3(1.5-3)$ & 0.04 \\
Cyclooxygenase-1 & $0(0-0.75)$ & $3(2.25-3)$ & 0.015 \\
Cyclooxygenase-2 & $1(0.25-1)$ & $3(1.5-3)$ & 0.04 \\
Surfactant protein A & $2.5(2-3)$ & $0(0-0.75)$ & 0.017 \\
Surfactant protein B & $2.5(2-3)$ & $0.5(0-1)$ & 0.018
\end{tabular}




\begin{tabular}{llll} 
Continued Table 1 & & & \\
Surfactant protein C & $3(2.25-3)$ & $0(0-0.75)$ & 0.015 \\
\hline Surfactant protein D & $3(3-3)$ & $0.5(0-1.75)$ & 0.013 \\
\hline Pro-surfactant protein B & $3(3-3)$ & $0.5(0-1)$ & 0.013 \\
\hline Placenta & & & \\
\hline Interleukin-1 & $0(0-0.75)$ & $3(3-3)$ & 0.011 \\
\hline Interleukin-4 & $0.5(0-1)$ & $3(2.25-3)$ & 0.017 \\
\hline Interleukin-6 & $0.5(0-1)$ & $3(2.25-3)$ & 0.015 \\
\hline Interleukin-10 & $0(0-0.75)$ & $2.5(2-3)$ & 0.017 \\
\hline Interferon-alpha & $0(0-0.75)$ & $3(2.25-3)$ & 0.015 \\
\hline Interferon-beta & $0(0-0.75)$ & $3(1.5-3)$ & 0.022 \\
\hline $\begin{array}{l}\text { Tumor necrosis factor- } \\
\text { alpha }\end{array}$ & $0(0-0.75)$ & $3(2.25-3)$ & 0.015 \\
\hline Caspase 3 & $0(0-0.75)$ & $3(3-3)$ & 0.011 \\
\hline Caspase 5 & $0(0-0.75)$ & $2.5(2-3)$ & 0.017 \\
\hline Caspase 7 & $0(0-0.75)$ & $2.5(2-3)$ & 0.017 \\
\hline Cyclooxygenase-1 & $1(0.25-1)$ & $2.5(2-3)$ & 0.017 \\
\hline Cyclooxygenase-2 & $0(0-0)$ & $3(2.25-3)$ & 0.011 \\
\hline Data are expresed & & & \\
\hline
\end{tabular}

Data are expressed as medians with interquartile ranges within brackets. Staining intensity was graded as follows: $0=$ negative, $1=$ weak staining, $2=$ moderate staining, and 3=diffuse staining

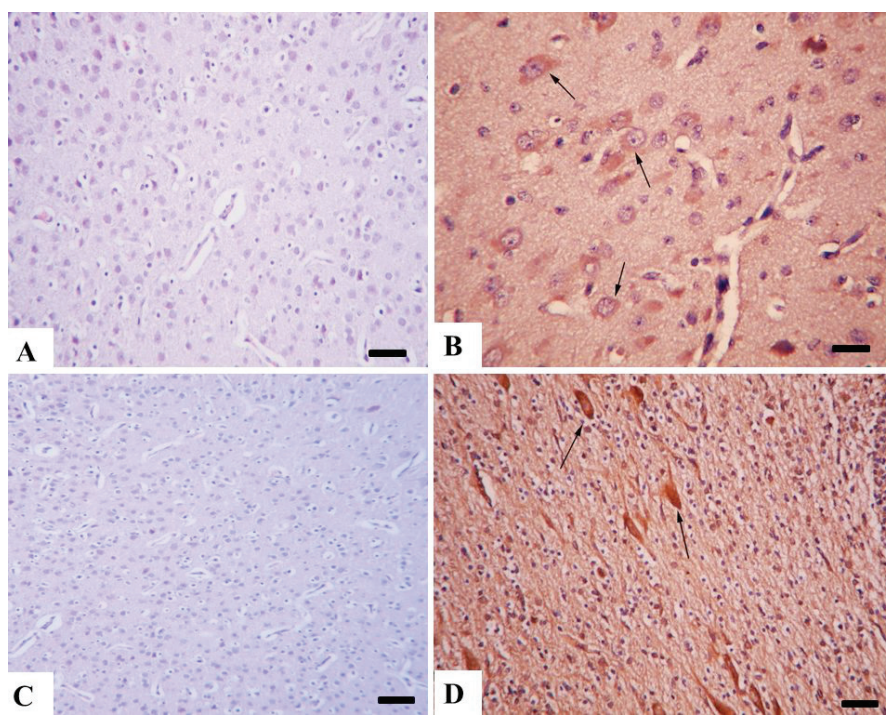

Figure 3. Brain immunohistochemistry. (A) Negative caspase-5 immunoreaction in the control group, Bar $=100 \mu \mathrm{m}$. (B) Increased caspase-5 immunoreaction in neurons (arrows) from the model group, Bar=50 $\mu \mathrm{m}$. (C) Negative COX-1 immunoreaction in the control group, Bar $=100 \mu \mathrm{m}$. (D) Marked COX-1 reaction in the model group, Bar=100 $\mu \mathrm{m}$

markers' expirations were increased in the lungs of endotoxinexposed kids (Figure 5, Figure 6).

In the model group, brain and lungs tissues were severely affected (Figure 7). Ultrastructural examination of the
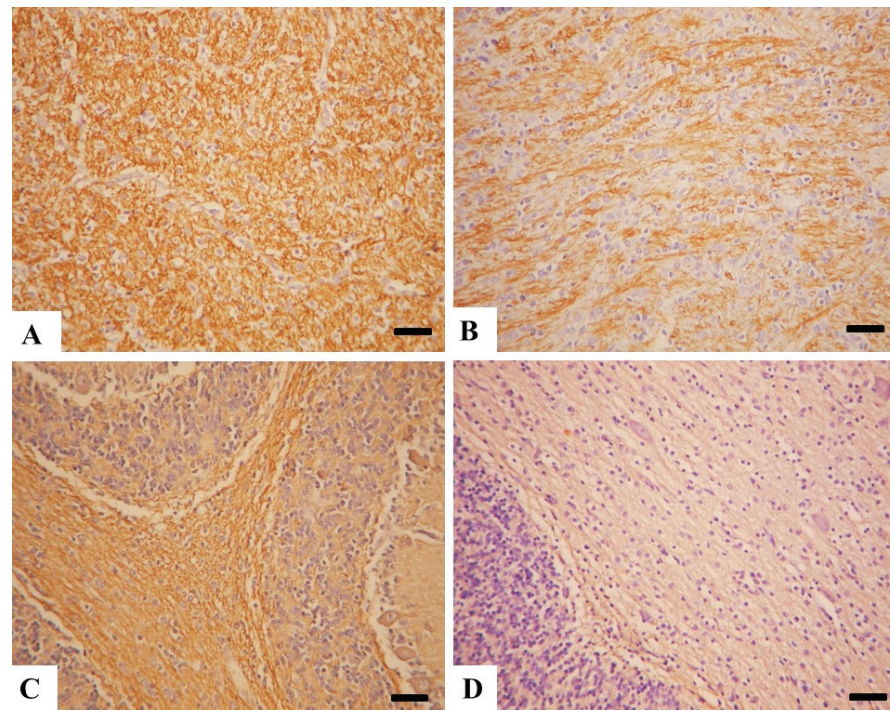

Figure 4. Brain tissue markers immunohistochemistry. (A) Marked myelin basic protein immunoreaction in a control brain, Bar=100 $\mu \mathrm{m}$. (B) Decreased myelin basic protein expiration in the model group, Bar=100 $\mu \mathrm{m}$. (C) Marked neurofilament protein immunopositive reaction in the control group, Bar=100 $\mu \mathrm{m}$. (D) Markedly reduced neurofilament protein expiration in the model group, Bar $=100 \mu \mathrm{m}$, streptavidin biotin peroxidase method

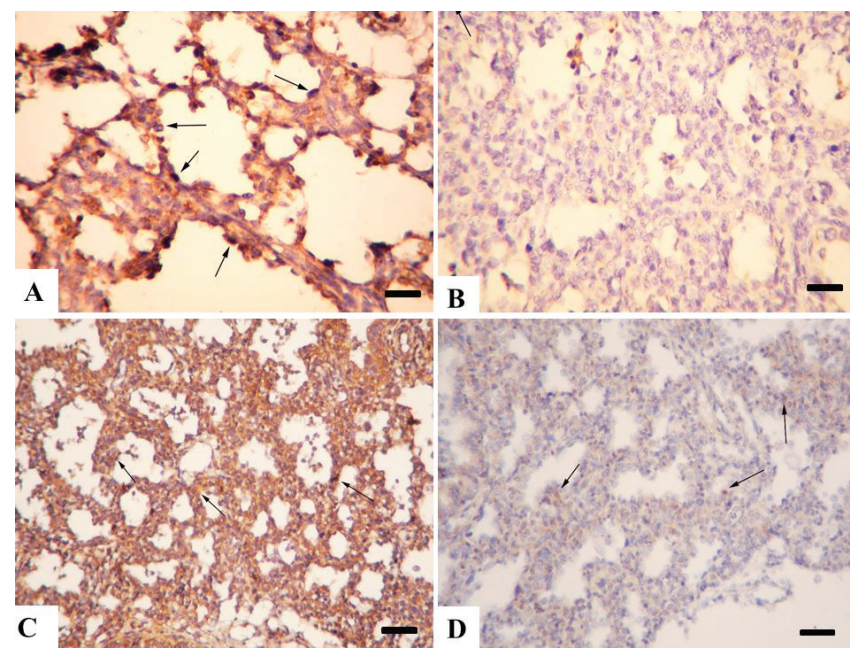

Figure 5. Lung immunohistochemistry (A) Strong SP-A expiration from alveolar cells (arrows) in a lung from the control group, Bar $=100 \mu \mathrm{m}$. (B) Decreased SP-A expiration from alveolar cells (arrows) in the model group, Bar=100 $\mu \mathrm{m}$. (C) Marked SP-B reaction in lung epithelial cells (arrows) in the control group, Bar $=200 \mu \mathrm{m}$. (D) Decreased SP-B immunoreaction in alveolar cells in lungs from the model group, Bar $=100 \mu \mathrm{m}$

brain specimens revealed chromatin margination at the nuclei accompanied by membrane damage and tissue lysis. Pulmonary specimens revealed blebbing at alveolar and bronchiolar cells. Mitochondrial damage and accompanying blebbing formations were also observed (Figure 7). 


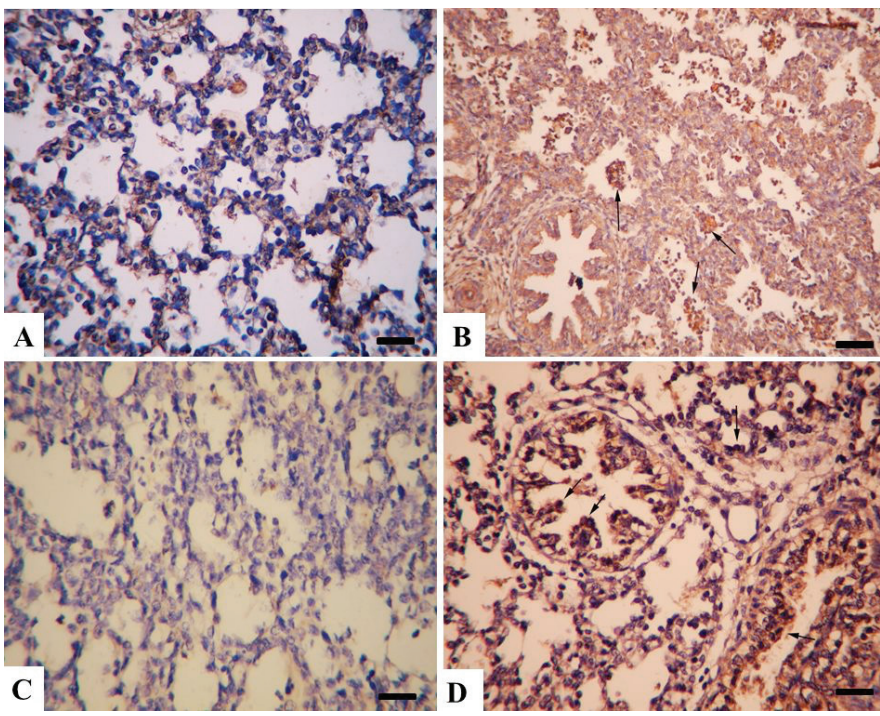

Figure 6. Lung interleukin (IL)-1 and caspase-5 immunohistochemistry. (A) Very slight IL-1 immunoreaction in the control group, Bar=100 $\mu \mathrm{m}$. (B) Marked increase in IL-1 expiration from alveolar macrophages (arrows) in the model group, Bar=100 $\mu \mathrm{m}$. (C) Negative caspase-5 expression in the control group, Bar $=100 \mu \mathrm{m}$. (D) Increased caspase-5 immunoreaction in bronchiolar cells (arrows) in a kid's lung from the model group, Bar=100 $\mu \mathrm{m}$, streptavidin biotin peroxidase method

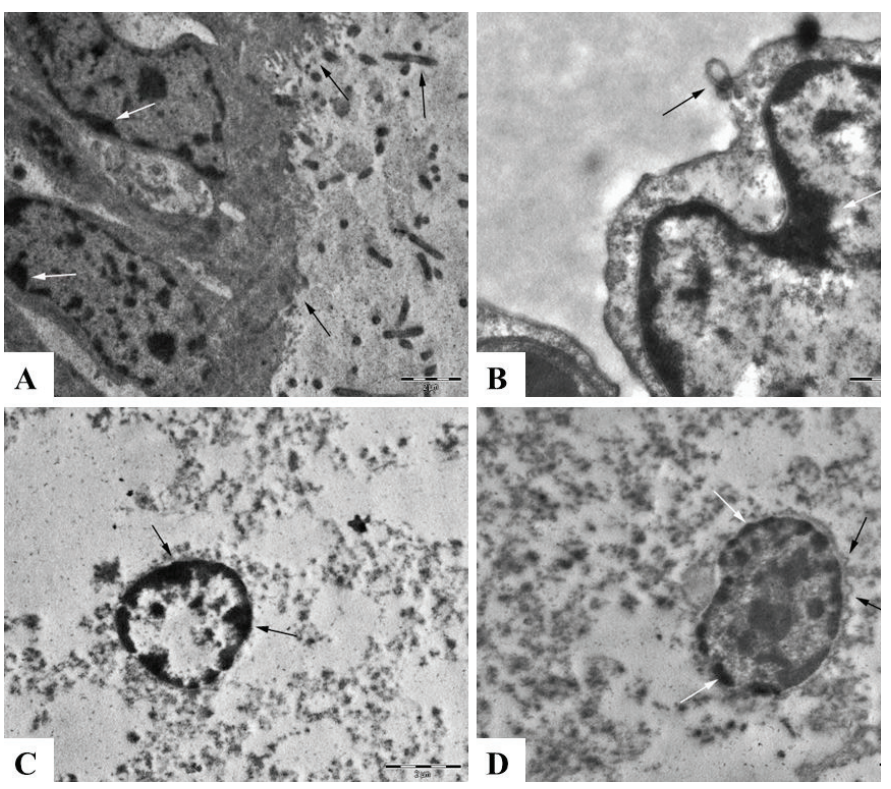

Figure 7. Electron microscopic findings in the model group, (A) Marked ciliary loss (black arrows) and chromatin marginations (white arrows) from lung cells, Bar $=2 \mu \mathrm{m}$, (B) Blebbing at nuclear membrane (black arrow) and chromatin margination (white arrow) in the nucleus of a lung cell, Bar=l $\mu \mathrm{m},(\mathrm{C})$ Severe necrotic changes, organelle lysis and chromatin marginations (arrows) in a neuron, Bar $=2 \mu \mathrm{m}$, (D) Blebbings at nuclear membrane (black arrows) and chromatin marginations (white arrows) in a neuron, Bar $=2 \mu \mathrm{m}$
Comparisons of interleukin (IL) and TNF-alpha levels measured by ELISA in the fetal serum and amniotic fluid samples are summarized in Table 2. Pregnancies in the model group had higher mean IL-1, 4, 6, 10 and TNF-alpha in the fetal plasma and amniotic fluid samples that were retrieved at day 115 (before endotoxin administration) and at day 120 (during preterm delivery). However, comparisons of differences over time (day 120 minus day 115) across the groups revealed no significant differences (Table 2).

IL-1, IL-4, IL-6, IL-10, and TNF-alpha levels showed nonsignificant increments both in the control $(\mathrm{p}=0.141, \mathrm{p}=0.461$, $\mathrm{p}=0.066, \mathrm{p}=0.066$ and $\mathrm{p}=0.066$, respectively) and the study groups $(\mathrm{p}=0.461, \mathrm{p}=0.461, \mathrm{p}=0.461, \mathrm{p}=0.18$ and $\mathrm{p}=0.066$, respectively).

\section{Discussion}

According to our findings, the use of maternal G-CSF without fetal catheterization followed by high-dose IA endotoxin is effective to induce fetal funisitis as well as fetal brain and lung injury. The suggested model can be used in experimental research to test the efficacy of potential drugs for the prevention of inflammation-related preterm labor.

Certain models to induce subchronic chorioamnionitis associated with preterm delivery have been used in the medical literature. The most common animal model includes the injection of endotoxin, i.e. lipopolysaccharides (LPS) usually isolated from E. coli(1-3,5-7,13). Although endotoxin has been injected into the maternal peritoneum ${ }^{(14)}$ or directly into the uterine horns ${ }^{(15)}$ of small animals such as rat and rabbit, IA administration generates one of the most plausible models, similar to the human disorder. Therefore, many experimental models used small ruminant models such as pregnant sheep and goat to induce chorioamnionitis and subsequent fetal injury by injecting endotoxin into the amniotic fluid under ultrasound guidance ${ }^{(13)}$. Fetal administrations of IA endotoxin to induce inflammation are technically difficult in smaller animals, but are feasible in the pregnant sheep and goat. Moreover, small ruminant models are convenient for evaluating novel fetal therapy modalities against fetal injury, as tissue harvesting and adequate sampling of amniotic fluid or fetal plasma are easier ${ }^{(16)}$.

Ureoplasma species, especially Ureoplasma pavum serovars of up to $2 \times 10^{7}$ Colony Forming Units have also been used to induce chorioamnionitis in pregnant sheep ${ }^{(17)}$. However, Ureoplasma alone seems to cause modest responses and may down-regulate LPS-induced proinflammatory cytokines ${ }^{(18)}$.

The endotoxin dose given into the amniotic cavity of the ewes has mostly been $10 \mathrm{mg}$ LPS. However, different doses such as $1 \mathrm{mg}, 4 \mathrm{mg}, 20 \mathrm{mg}$, and $100 \mathrm{mg}$ were also evaluated and were reported not to alter birth weight or umbilical arterial blood $\mathrm{pH}$ and partial carbon dioxide values relative to controls $^{(19)}$. Moreover, even ultra-high IA doses (100 $\mathrm{mg}$ ) were not associated with fetal deaths in the sheep 
Table 2. Comparisons of enzyme-linked immunosorbent assay results across the groups

\begin{tabular}{|c|c|c|c|}
\hline Marker & Group 1 controls & Group 2 model & p-value \\
\hline \multicolumn{4}{|l|}{ Fetal plasma } \\
\hline Interleukin-1 (pg/mL) & $63(55-91)$ & $141(125-161)$ & 0.02 \\
\hline Interleukin-6 (pg/mL) & $44(42-48)$ & $164(123-180)$ & 0.005 \\
\hline Interleukin-10 (pg/mL) & $23(16-26)$ & $100(69-104)$ & 0.005 \\
\hline \multicolumn{4}{|l|}{ Amniotic fluid (day 115) } \\
\hline Interleukin-1 (pg/mL) & $76(68-93)$ & $200(153-240)$ & 0.012 \\
\hline Interleukin-4 (pg/mL) & $72(69-135)$ & $437(429-593)$ & 0.002 \\
\hline Interleukin-6 (pg/mL) & $56(49-58)$ & $158(136-200)$ & 0.008 \\
\hline Interleukin-1 (pg/mL) & $95(87-102)$ & $207(200-245)$ & 0.002 \\
\hline Interleukin-4 (pg/mL) & $105(83-144)$ & $475(462-579)$ & 0.0001 \\
\hline Interleukin-6 (pg/mL) & $60(52-79)$ & $180(173-236)$ & 0.003 \\
\hline Interleukin-10 (pg/mL) & $31(28-34)$ & $105(100-117)$ & 0.0001 \\
\hline Tumor necrosis factor-alpha (pg/mL) & $112(109-118)$ & $302(294-303)$ & 0.0001 \\
\hline \multicolumn{4}{|c|}{ Change in amniotic fluid (day 120 minus day 115) } \\
\hline Interleukin-1 (pg/mL) & $19(-6-35)$ & $7(-40-92)$ & 0.686 \\
\hline Interleukin-4 (pg/mL) & $14(-17-58)$ & $25(-110-143)$ & 0.686 \\
\hline
\end{tabular}

Data are expressed as median values with interquartile ranges within brackets

model $^{(19)}$. Interestingly, relatively low doses of IA endotoxin were associated with increased fetal pulmonary maturation (instead of injury) in some investigations ${ }^{(5,6)}$. It is possible that IA endotoxin stimulates lung maturation by a mechanism distinct from glucocorticoids ${ }^{(19)}$.

The finding that low doses of IA endotoxin may paradoxically prevent fetal lung injury led investigators to modify animal models of chorioamnionitis and fetal injury. Watanabe at al. ${ }^{(7)}$ suggested that fetal G-CSF pretreatment before activation in utero by an IA infusion is $100 \%$ effective to induce necrotizing funisitis. This assumption depends on the observation that preterm neonates born following chorioamnionitis had significantly higher umbilical cord G-CSF levels than those without chorioamnionitis ${ }^{(20)}$. Moreover, fetuses with fetal inflammatory syndrome were found to have high median fetal plasma G-CSF concentrations ${ }^{(21,22)}$.

It is known that low-grade systemic inflammatory response is an important component of fetal brain injury ${ }^{(1)}$. Therefore, pretreatment with fetal G-CSF may exacerbate inflammation in the umbilical cord and the fetus. Furthermore, necrotizing funisitis has been reported as an important risk factor for the development of chronic lung disease in the human ${ }^{(23)}$. Therefore, the induction of necrotizing funisitis in an experimental animal model has the potential to simulate the severe form of neonatal injury. Overall, these data ${ }^{(7,20-23)}$ support the notion that exacerbated inflammation by G-CSF and high-dose endotoxin causes substantial fetal lung and brain injury, as opposed to fetal pulmonary maturational or protective effects observed with low-dose IA endotoxin injections.

Depending on these previous data, we developed our model in goat pregnancy by modifying the setting described by Watanabe at al. ${ }^{(7)}$. These authors performed a laparotomy and hysterotomy to catheterize fetal carotid arteries chronically. At least $48 \mathrm{~h}$ after surgery, catheterized fetuses received daily bolus infusions of G-CSF from day 125 to day 129 of gestation. While on fetal G-CSF pretreatment, $20 \mathrm{mg}$ of endotoxin was 
administered intra-amniotically at day 127 . The investigators reported $100 \%$ success rate with the model, with all animals developing necrotizing funisitis ${ }^{(7)}$.

We modified the experimental model by Watanabe et al. ${ }^{(7)}$ and preferred giving G-CSF to the doe (mother) instead of performing chronic fetal arterial catheterization, a technically demanding intervention. G-CSF was shown to cross the placenta in previous human and animal studies ${ }^{(24-26)}$. G-CSF was measurable in the amniotic fluid and fetal plasma of pregnant mice $30 \mathrm{~min}$ after injection, with a peak concentration reached at 2 to $4 \mathrm{~h}$. Relatively high concentrations revealed that a functional placental receptor was not essential for the transfer of G-CSF across the placenta ${ }^{(25)}$. Similar results were obtained in rat models, demonstrating that maternally administered G-CSF crosses the placenta and has myelopoietic effects even at low concentrations in the fetus ${ }^{(26)}$.

G-CSF is generally considered safe in pregnancy. Although we were not able to locate any information on potential side effects of G-CSF particularly in pregnant goats, data from other species including humans demonstrate no significant adverse effects during pregnancy ${ }^{(7,27)}$. In a recent report ${ }^{(28)}$, rates of spontaneous terminations, preterm births, maternal infections, and neonatal adverse events were similar in women with and without G-CSF therapy during pregnancy. These results ${ }^{(24-28)}$ led us to administer G-CSF directly into the venous circulation of the does. We believe this has two advantages. First, a low-grade inflammation was induced in the maternal compartment. This conforms to the human preterm birth cascades associated with early maternal infection/inflammation. Second, G-CSF in the maternal compartment is expected to cross the placenta, obviating the need for direct fetal arterial administrations. Another modification in our design was the administration of IA endotoxin by the completion of the 5-day course of maternal G-CSF injections. We suppose this is more coherent with the fetal inflammatory response syndrome, in which lowgrade preclinical systemic maternal and IA inflammation is followed by a relatively abrupt insult that leads to fetal brain injury and preterm delivery.

Inflammatory markers including interleukin- 1,4 , and 6 and COX-1 and COX-2 were increased in the fetal tissues and placenta of our model pregnancies. Apoptosis in terms of caspase 3,5, and 7 was also prominent in all those tissues. Fetal brain injury was shown in the model kids, as expressions of markers such as vimentin, NSE, NFP, GFAP, MBP, and APAF-1 were all decreased. Significant fetal inflammation was additionally proved by increased interleukin and TNF concentrations in the fetal plasma and amniotic fluid.

An interesting finding of our study was lack of significant change in certain amniotic fluid inflammatory markers between day 115 and day 120. This held true for both of the groups, suggesting that IA interleukin-1, 4, 6, 10 and TNF-alpha levels were comparable 5 days after IA endotoxin exposure. In fact, these data are in line with previous findings indicating maximally induced cytokine mRNAs within only 5 $\mathrm{h}$ after IA endotoxin administration and decreasing to control values by 2 days ${ }^{(29)}$. Therefore, our design with a sampling interval of 5 days probably did not allow detecting the early and rapid elevation of IA interleukins.

Interleukin-10 is an anti-inflammatory cytokine, capable of inhibiting synthesis of pro-inflammatory cytokines. We found increased interleukin-10 staining in the fetal brain, fetal lung, and the placenta of exposed animals compared to controls. Interleukin-10 plasma concentrations were also higher in the model animals. Although these results seem contradictory, they support previous human and animal data, denoting increased amniotic fluid and fetal tissue levels of interleukin-10 during IA infection and/or inflammation. In a recent ovine study that used IA endotoxin ${ }^{(30)}$, interleukin-1, 6, 8, TNF-alpha, and interleukin-10 mRNA were all reported to be increased similar to our findings. Overall, our data support increased reflex anti-inflammatory processes in our design and the involved setting.

\section{Study Limitations}

We did not specifically evaluate physiological parameters such as fetal heart rates and arterial or amniotic pressures, as these were not part of our original experimental design. We were not able to track changes in leukocyte count or activity during the study period in the groups. Due to ethical reasons, our design did not include groups that were given only G-CSF and given only endotoxin to observe independent effects on inflammation separately. Despite these drawbacks, our robust design proved that the present novel and customized experimental model leads to profound IA and fetal inflammation as well as fetal injury, shown repeatedly by ELISA, immunohistochemistry, and electron microscopy results. Moreover, our model consistently resulted in necrotizing funisitis, which is a predictor of chronic lung disease and impaired neurological outcome.

\section{Conclusion}

The supposed small ruminant experimental design, which includes maternal i.v. G-CSF followed by $20 \mathrm{mg}$ of IA endotoxin is a feasible model to aggravate intrauterine inflammation and fetal lung/brain injury and will have potential use for research in that specific area.

\section{Ethics}

Ethics Committee Approval: The study protocol was subject to animal ethics committee approval by Süleyman Demirel University Animal Experimentation Local Ethics Committee (approval date and no, 23.08.2011/03).

Informed Consent: Experimental study.

Peer-review: External and internal peer-reviewed. 


\section{Authorship Contributions}

Concept: M.S., A.K., Ö.Ö., M.H., D.K., A.A., O.Ö. Design: M.S., A.K., D.K. Data Collection or Processing: M.S., A.K., Ö.Ö., M.H., D.K., A.A., O.Ö. Analysis or Interpretation: M.S., Ö.Ö, M.H, O.Ö. Literature Search: M.S., A.F, O.Ö., Writing: M.S., Ö.Ö.

Conflict of Interest: No conflict of interest was declared by the authors.

Financial Disclosure: The present study was supported by funds from the Scientific and Technological Research Council of Turkey (research project no, 111S424).

\section{References}

1. Hagberg H, Peebles D, Mallard C. Models of white matter injury: comparison of infectious, hypoxic-ischemic, and excitotoxic insults. Ment Retard Dev Disabil Res Rev 2002;8:30-8.

2. Gavilanes AW, Strackx E, Kramer BW, Gantert M, Van den Hove $\mathrm{D}$, Steinbusch $\mathrm{H}$, et al. Chorioamnionitis induced by intraamniotic lipopolysaccharide resulted in an interval-dependent increase in central nervous system injury in the fetal sheep. Am J Obstet Gynecol 2009;200:437.el-8

3. Miura A, Yoneyama Y, Sawa R, Araki T. Fetal plasma prostaglandin $\mathrm{F}$ (2alpha) and cortisol responses to high-dose endotoxin administration in fetal goats. J Nippon Med Sch 2003;70:151-6.

4. Hamilton JA, Achuthan A. Colony stimulating factors and myeloid cell biology in health and disease. Trends Immunol 2013;34:81-9.

5. Moss TJ, Newnham JP, Willett KE, Kramer BW, Jobe AH, Ikegami M. Early gestational intra-amniotic endotoxin: lung function, surfactant, and morphometry. Am J Respir Crit Care Med 2002;165:805-11.

6. Kuypers E, Collins JJ, Kramer BW, Ofman G, Nitsos I, Pillow JJ, et al. Intra-amniotic LPS and antenatal betamethasone: inflammation and maturation in preterm lamb lungs. Am J Physiol Lung Cell Mol Physiol 2012;302:L380-9.

7. Watanabe T, Matsuda T, Hanita T, Okuyama K, Cho K, Kobayashi $\mathrm{K}$, et al. Induction of necrotizing funisitis by fetal administration of intravenous granulocyte-colony stimulating factor and intra-amniotic endotoxin in premature fetal sheep. Pediatr Res 2007;62:670-3.

8. Sezik M, Koker A, Ozmen O, Haligur M, Ince D, Aydogan A, et al. Antenatal pentoxifylline therapy to prevent endotoxin-induced fetal injury in the preterm goat model. In: Ultrasound in Obstetrics \& Gynecology Supplement: Abstracts of the 24th World Congress on Ultrasound in Obstetrics Gynecology; 14-17 September 2014; Barcelona, Spain; International Society of Ultrasound in Obstetrics Gynecology; 2014. p. 310.

9. Sezik M, Ozkaya O, Arslanoglu E, Koker A, Cetin H, Ozbasar D, et al. Evaluation of intra-amniotic surfactant administration for lung maturation in preterm sheep. J Exp Anim Sci 2007;43:301-7.

10. Frandson RD, Wilke WL, Fails AD. Anatomy and physiology of farm animals. 7th ed. Singapore: Wiley-Blackwell; 2009.

11. Sezik M, Antalyali M, Ozmen O, Haligur M, Koker A, Ozkaya O, et al. Ultra-high dose of intra-amniotic or direct fetal intramuscular betamethasone for lung maturation in the preterm goat model. Eur J Obstet Gynecol Reprod Biol 2012;164:15-23.

12. Antalyalı M, Ozmen O, Halıür M, Sezik M. Fetal pulmonary injury following single high-dose intra-amniotic betamethasone treatment in preterm goat kids. J Turk Ger Gynecol Assoc 2012;13:242-6.

13. Kemp MW, Saito M, Newnham JP, Nitsos I, Okamura K, Kallapur SG. Preterm birth, infection, and inflammation advances from the study of animal models. Reprod Sci 2010;17:619-28.
14. Cai Z, Pan ZL, Pang Y, Evans OB, Rhodes PG. Cytokine induction in fetal rat brains and brain injury in neonatal rats after maternal lipopolysaccharide administration. Pediatr Res 2000;47:64-72.

15. Debillon T, Gras-Leguen C, Vérielle V, Winer N, Caillon J, Rozé JC, et al. Intrauterine infection induces programmed cell death in rabbit periventricular white matter. Pediatr Res 2000;47:736-42.

16. Barry JS, Anthony RV. The pregnant sheep as a model for human pregnancy. Theriogenology 2008;69:55-67.

17. Kramer BW. Chorioamnionitis - new ideas from experimental models. Neonatology 2011;99:320-5.

18. Snyder CC, Wolfe KB, Gisslen T, Knox CL, Kemp MW, Kramer BW, et al. Modulation of lipopolysaccharide-induced chorioamnionitis by Ureaplasma parvum in sheep. Am J Obstet Gynecol 2013;208:399. el-8.

19. Jobe AH, Newnham JP, Willet KE, Moss TJ, Gore Ervin M, Padbury JF, et al. Endotoxin-induced lung maturation in preterm lambs is not mediated by cortisol. Am J Respir Crit Care Med 2000;162:1656-61.

20. Li Y, Ohls RK, Rosa C, Shah M, Richards DS, Christensen RD. Maternal and umbilical serum concentrations of granulocyte colony-stimulating factor and its messenger RNA during clinical chorioamnionitis. Obstet Gynecol 1995;86:428-32.

21. Chaiworapongsa T, Romero R, Berry SM, Hassan SS, Yoon BH, Edwin $\mathrm{S}$, et al. The role of granulocyte colony-stimulating factor in the neutrophilia observed in the fetal inflammatory response syndrome. J Perinat Med 2011;39:653-66.

22. Goldenberg RL, Andrews WW, Mercer BM, Moawad AH, Meis PJ, Iams JD, et al. The preterm prediction study: granulocyte colonystimulating factor and spontaneous preterm birth. National Institute of Child Health and Human Development Maternal-Fetal Medicine Units Network. Am J Obstet Gynecol 2000;182:625-30.

23. Matsuda T, Nakajima T, Hattori S, Hanatani K, Fukazawa Y, Kobayashi $\mathrm{K}$, et al. Necrotizing funisitis: clinical significance and association with chronic lung disease in premature infants. Am J Obstet Gynecol 1997;177:1402-7.

24. Calhoun DA, Rosa C, Christensen RD. Transplacental passage of recombinant human granulocyte colony-stimulating factor in women with an imminent preterm delivery. Am J Obstet Gynecol 1996;174:1306-11.

25. Calhoun DA, Gersting JA, Lunøe M, Du Y, Christensen RD. Transfer of recombinant human granulocyte colony stimulating factor (rhGCSF) from the maternal to the fetal circulation is not dependent upon a functional G-CSF-receptor. Placenta 2001;22:609-12.

26. Medlock ES, Kaplan DL, Cecchini M, Ulich TR, del Castillo J, Andresen J. Granulocyte colony-stimulating factor crosses the placenta and stimulates fetal rat granulopoiesis. Blood 1993;81:91622.

27. Pessach I, Shimoni A, Nagler A. Granulocyte-colony stimulating factor for hematopoietic stem cell donation from healthy female donors during pregnancy and lactation: what do we know? Hum Reprod Update 2013;19:259-67.

28. Boxer LA, Bolyard AA, Kelley ML, Marrero TM, Phan L, Bond JM, Newburger PE, Dale DC. Use of granulocyte colony-stimulating factor during pregnancy in women with chronic neutropenia. Obstet Gynecol 2015;125:197-203. 29.

29. Kallapur SG, Willet KE, Jobe AH, Ikegami M, Bachurski CJ. Intraamniotic endotoxin: chorioamnionitis precedes lung maturation in preterm lambs. Am J Physiol Lung Cell Mol Physiol 2001;280:L527-36.

30. Schmidt AF, Kannan PS, Kemp MW, Kramer BW, Newnham JP, Jobe $\mathrm{AH}$, et al. Intra-amniotic LPS modulates expression of antimicrobial peptides in the fetal sheep lung. Pediatr Res 2014;76:441-7. 